\title{
Communication Ethics In Online Learning Throungh The Zoom Application
}

\section{Etika Komunikasi Dalam Pembelajaran Online Melalui Aplikasi Zoom}

\author{
Novi Sulianti ${ }^{1)}$; Asnawati ${ }^{2)}$; Yanto ${ }^{2)}$ \\ 1, 2) Department of Communication, Faculty of Social Sciences, Universitas Dehasen \\ Bengkulu \\ Email: asnawati@unived.ac.id
}

\begin{abstract}
How to Cite :
Sulianti, N., Asnawati., Yanto. (2021). Communication Ethics In Online Learning Throungh The Zoom Application. Sengkuni Journal: Social Sciences and Humanities Vol. 2 No. 12021 page: 80-88. DOI: https://doi.org/10.37638/sengkuni.2.1.81-88
\end{abstract}

\section{ARTICLE HISTORY}

Received [03 May 2021]

Revised [06 June 2021]

Accepted [22 June 2021]

\section{KEYWORDS}

Communication

Ethics, Online Learning,

Zoom Application
This is an open access article under the $\underline{C C-B Y-S A}$ license

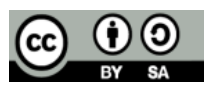

\section{ABSTRAK}

Penelitian ini bertujuan untuk mengetahui etika komunikasi mahasiswa kepada dosen dan etika mahasiswa kepada sesama mahasiswa dalam pembelajaran online melalui aplikasi zoom pada mahasiswa Fakultas IImu-IImu Sosial. Metode penelitian ini adalah fleld research dengan pendekatan kualitatif. Pengumpulan data dilakukan dengan teknik observasi, wawancara dan dokumentasi. Teori yang digunakan pada penelitian ini adalah Etika Komunikai Burhannudin Salam, Deskriptif dan normatif. Etika Deskriptif adalah mengenai nilai dan pola perilaku manusia sebagai suatu fakta, sedangkan Etika Normatif berbicara tentang norma atau aturan yang menuntun perilaku manusia. Narasumber penelitian ini adalah mahasiswa dan mahasiswi Fakultas IImu-IImu Sosial Universitas Dehasen Bengkulu. Hasil penelitian menunjukan etika komunikasi mahasiswa pada dosen masih ada beberapa orang yang tidak mengikuti aturan dan etikanya kurang baik pada dosen saat perkuliahan melalui aplikasi zoom, sedangkan etika mahasiswa kepada sesama mahasiswa saat mengikuti perkuliahan melalui aplikasi zoom sudah cukup baik walaupun masih ada beberapa orang mahasiswa yang masih tidak mengunakan etika dengan baik kepada sesama mahasiswa pada saat perkuliahan melalui aplikasi zoom berlangsung.

\section{ABSTRACT}

This study aims to determine the ethics of student communication to lecturers and student ethics to fellow students in online learning through the zoom application for students of the Faculty of Social Sciences. This research method is fleld research with a qualitative approach. The data was collected by means of observation, interview and documentation techniques. The theory used in this study is Burhannudin Salam's Communicating Ethics, descriptive and normative. Descriptive Ethics is about values and patterns of human behavior as a fact, while Normative Ethics talks about norms or rules that guide human behavior. The sources of this research were students and students of the Faculty of 
Social Sciences, Dehasen University Bengkulu. The results show that there are still some people who do not follow the rules and ethics of student communication to lecturers during lectures through the zoom application, while the ethics of students towards fellow students when taking lectures through the zoom application is quite good even though there are still some students who still do not use ethics properly to fellow students during lectures through the zoom application in progress.

\section{PENDAHULUAN}

Menurut Abdurahman dan Riswaya ( 2014 ), aplikasih adalah program siap pakai yang dapat digunakan untuk menjalankan perintah-perintah dari pengguna aplikasi tersebut dengan tujuan mendapatkan hasil yang lebih akurat sesuai dengan tujuan pembuatan aplikasi tersebut, aplikasi mempunyai arti yaitu pemecahan masalah yang menggunakan salah satu teknik pemrosesan data aplikasi yang biasanya berpacu pada sebuah komputansi yang diinginkan atau diharapkan maupun pemberosesan data yang diharapkan. Pengertian aplikasi secara umum adalah alat terapan yang difungsikan secara khusus dan terpadu sesuai kemampuan yang dimilikinya, aplikasi merupakan suatu perangkat computer yang siap pakai bagi user.

Aplikasi sering juga disebut sebagai perangkat lunak, merupakan program komputer yang isi instruksinya dapat diubah dengan mudah. Aplikasi pada umumnya digunakan untuk mengontrol perangkat keras (yang sering disebut sebagai device driver), melakukan proses perhitungan, dan berinteraksi dengan aplikasi yang lebih mendasar lainnya (seperti sistem operasi, dan bahasa pemrograman). Secara umum aplikasi dapat dibagi menjadi 3 tingkatan yaitu tingkatan program aplikasi (aplikasi program misalnya Microsoft Office), tingkatan sistem operasi (operating system misalnya Microsoft Windows), dan tingkatan bahasa pemrograman (misalnya PHP). Menurut Dabbagh dan Ritland ( 2005:15) pembelajaran online adalah system belajar yang terbuka dan tersebar dengan menggunakan perangkat pedagogi ( alat bantu pendidikan ), yang dimungkinakan melalui internet dan teknologi berbasis jaringan untuk mempasilitasi pembentukan proses belajar dan pengetahuan melalui aksi dan interaksi yang berarti.

Menurut ( K.Bertens ) etika komunikasi ialah dikaitkan dengan watak atau kesusilaan yang menentukan benar atau tidaknya cara penyampaian pesan kepada orang lain yang dapat mengubah sikap, pendapat, atau perilaku baik secara lisan ataupun tidak langsung. Etika komunikasi merupakan nilai-nilai dan norma-norma moral, yang menjadikan pegangan bagi seseorang atau suatu kelompok dalam mengatur perilaku. Dari hasil observasi awal penulis mengamati etika mahasiswa kepada dosen yang kurang baik dan tidak mencerminkan sebagai mahasiswa saat melakukan kuliah online melalui aplikasi zoom, seharusnya sebagai mahasiswa ketika melakukan kuliah online bisa mengikuti prosedur layaknya kuliah tatap muka yang biasanya dilakukan didalam kelas seperti: memakai baju yang sopan, berbicara yang baik, tidak berbicara kepada orang lain ketika lagi melakukan kuliah online dan tidak sambil makan atau minum.

\section{LANDASAN TEORI Etika Komunikasi, Pembelajaran Online}

Etika deskriptif yang berusaha meneropong secara kritis dan rasional sikap dan pola perilaku manusia dan apa yang dikejar oleh manusia dalam hidup ini sebagai 
sesuatu yang bernilai. Etika deskriptif berbicara mengenai fakta apa adanya, yaitu mengenai nilai dan pola perilaku manusia sebagai suatu fakta yang terkait dengan situasi dan realitas konkret yang membudaya. la berbicara mengenai kenyataan penghayatan nilai, tanpa menilai, dalam suatu masyarakat, tentang sikap orang menghadapi hidup ini, dan tentang kondisi-kondisi yang memungkinkan manusia bertindak secara etis.Contoh dari etika deskriptif ialah seperti menjaga sopan satun ketika lagi berbicara didepan umum, menjaga sikap ketika bertamu, bersikap sopan kepada orang yang lebih tua seperti: jangan bermain hp ketika lagi berbicara. Etika ialah menetapkan sikap dan pola perilaku yang ideal yang seharusnya dimiliki oleh manusia dalam bertindak. Jadi etika ini berbicara tentang Norma-norma yang menuntun perilaku manusia serta memberi penilaian dan hiambauan kepada manusia untuk bertindak sebagaimana seharusnya Dengan Demikian etika normatif memberikan petunjuk secara jelas bagaimana manusia harus hidup secara baik dan menghindari diri dari yang jelek.

Dalam pergaulan sehari-hari kita menemukan berbagai etika normative yang menjadi pedoman bagi manusia untuk bertindak. Norma-norma tersebut sekaligus menjadi dasar penilaian bagi manusia baik atau buruk, salah atau benar.Contoh dari etika normative ini ialah seperti kejujuran, disiplin, dan lain-lain. Secara umum normanorma tersebut dikelompokkan menjadi dua yaitu:

a. Norma Khusus adalah norma yang mengatur tingkah laku dan tindakan manusia dalam kelompok/bidang tertentu. Seperti etika medis, etika kedokteran, etika lingkungan, aturan main catur, aturan main bola, dll. Di mana aturan tersebut hanya berlaku untuk bidang khusus dan tidak bisa mengatur semua bidang. Misal: aturan main catur hanya bisa dipakai untuk permainan catur dan tidak bisa dipakai untuk mengatur permainan bola.

b. Norma Umum justru sebaliknya karena norma umum bersifat universal, yang artinya berlaku luas tanpa membedakan kondisi atau situasi, kelompok orang tertentu. Secara umum norma umum dibagi menjadi tiga (3) bagian, yaitu :

- Norma sopan santun, yakni norma yang mengatur pola perilaku dan sikap lahiriah, misalnya : tata cara bertamu, duduk, makan, minum, dan sebagainya. Norma sopan santun ini lebih menyangkut tata cara lahiriah dan pergaulan sehari-hari. Walaupun sikap dan perilaku lahiriah ini bersumber dari dalam hati dan arena itu mempunyai kualitas moral, namun sikap lahiriah itu sendiri tidak bersifat moral.

- Norma hukum, yakni norma yang dituntut dengan tegas oleh masyarakat karena dianggap perlu demi keselamatan dan kesejahteraan masyarakat. Norma hukum ini lebih tegas dan pasti, karena dijamin oleh hukuman terhadap para pelanggarnya.

- Norma moral, yakni aturan mengenai sikap dan perilaku manusia sebagai manusia. Norma moral mengacu pada baik buruknya manusia sebagai manusia. Norma moral menjadi tolok ukur yang dipakai oleh masyarakat untuk menentukan baik buruknya manusia sebagai manusia, dan bukan dalam kaitannya dengan tugas atau jawaban tertentu, bukan dalam kaitan dengan status social dan sebagainya. Yang ditekankan adalah sikap mereka dalam menghadapi tugasnya, dalam menghargai kehidupan manusia, dalam menampilkan dirinya sebagai manusia dalam profesi yang diembannya.

Disamping teori-teori ini, mungkin lagi suatu pendekatan lain yang tidak menyoroti perbuatan, tetapi memfokuskan pada seluruh manusia sebagai pelaku moral. Teori tipe terakhir ini adalah teori keutamaan (virtue) yang memandang sikap atau akhlak seseorang. Dalam etika dewasa ini terdapat minat khusus untuk teori keutamaan sebagai 
reaksi atas teori-teori etika sebelumnya yang terlalu berat sebelah dalam mengukur perbuatan dengan prinsip atau norma. Namun demikian, dalam sejarah etika teori keutamaan tidak merupakan sesuatu yang baru. Sebaliknya, teori ini mempunyai suatu tradisi lama yang sudah dimulai pada waktu filsafat Yunani kuno. Keutamaan bisa didefinisikan sebagai berikut : disposisi watak yang telah diperoleh seseorang dan memungkinkan dia untuk bertingkah laku baik secara moral. Kebijaksanaan, misalnya, merupakan suatu keutamaan yang membuat seseorang mengambil keputusan tepat dalam setiap situasi. Keadilan adalah keutamaan lain yang membuat seseorang selalu memberikan kepada sesama apa yang menjadi haknya. Kerendahan hati adalah keutamaan yang membuat seseorang tidak menonjolkan diri, sekalipun situasi mengizinkan. Suka bekerja keras adalah keutamaan yang membuat seseorang mengatasi kecenderungan spontan untuk bermalas-malasan. Ada banyak keutamaan semacam ini. Seseorang adalah orang yang baik jika memiliki keutamaan. Hidup yang baik adalah hidup menurut keutamaan (virtuous life).

Menurut pemikir Yunani (Aristoteles), hidup etis hanya mungkin dalam polis. Manusia adalah "makhluk politik", dalam arti tidak bisa dilepaskan dari polis atau komunitasnya. Dalam etika bisnis, teori keutamaan belum banyak dimanfaatkan. Solomon membedakan keutamaan untuk pelaku bisnis individual dan keutamaan pada taraf perusahaan. Di samping itu ia berbicara lagi tentang keadilan sebagai keutamaan paling mendasar di bidang bisnis. Diantara keutamaan yang harus menandai pebisnis perorangan bisa disebut : kejujuran, fairness, kepercayaan dan keuletan. Keempat keutamaan ini berkaitan erat satu sama lain dan kadang-kadang malah ada tumpang tindih di antaranya Kejujuran secara umum diakui sebagai keutamaan pertama dan paling penting yang harus dimiliki pelaku bisnis. Kejujuran menuntut adanya keterbukaan dan kebenaran. Jika mitra bisnis ingin bertanya, pebisnis yang jujur selalu bersedia memberi keterangan. Tetapi suasana keterbukaan itu tidak berarti si pebisnis harus membuka segala kartunya. Sambil berbisnis, sering kita terlibat dalam negosiasi kadangkadang malah negosiasi yang cukup keras dan posisi sesungguhnya atau titik tolak kita tidak perlu ditelanjangi bagi mitra bisnis. Garis perbatasan antara kejujuran dan ketidakjujuran tidak selalu bisa ditarik dengan tajam.

Ketiga keutamaan lain bisa dibicarakan dengan lebih singkat. Keutamaan kedua adalah fairness. Fairness adalah kesediaan untuk memberikan apa yang wajar kepada semua orang dan dengan "wajar" dimaksudkan apa yang bisa disetujui oleh semua pihak yang terlibat dalam suatu transaksi. Insider trading adalah contoh mengenai cara berbisnis yang tidak fair. Dengan insider trading dimaksudkan menjual atau membeli saham berdasarkan informasi "dari dalam" yang tidak tersedia bagi umum. Bursa efek sebagai institusi justru mengandaikan semua orang yang bergiat disini mempunyai pengetahuan yang sama tentang keadaan perusahaan yang mereka jualbelikan sahamnya. Orang yang bergerak atas dasar informasi dari sumber tidak umum (jadi rahasia) tidak berlaku fair.

Kepercayaan (trust) juga merupakan keutamaan yang penting dalan konteks bisnis. Kepercayaan harus ditempatkan dalam relasi timbal balik. Ada beberapa cara untuk mengamankan kepercayaan. Salah satu cara adalah memberi garansi atau jaminan. Cara-cara itu bisa menunjang kepercayaan antara pebisnis, tetapi hal itu hanya ada gunanya bila akhirnya kepercayaan melekat pada si pebisnis itu sendiri.

\section{METODE PENELITIAN}

Dalam penelitian ini menggunakan penelitian lapangan (fleld research), yaitu dengan meneliti langsung pada objek yang diteliti yaitu menjadikan objek penelitiannya 
adalah Mahasiswa/i Universitas Dehasen Bengkulu. "'Sebagai prosedur penelitian yang menghasilkan data deskriptif berupa kata-kata tertulis atau lisan dari orang-orang dan perilaku yang dapat diamati (Moloeng,2004:3)". Teknik pemilihan informan dalam penelitian ini dengan menggunakan teknik purposive sampling. Purposive adalah pengambilan sampel yang berdasarkan atas pertimbangan tertentu seperti sifat-sifat populasi ataupun ciri-ciri yang sudah diketahui sebelumnya (Notoatmodjo, $2010: 34$ ).

\section{HASIL DAN PEMBAHASAN}

\section{Hasil dan Pembahasan}

Berdasarkan hasil penelitian dapat dilihat dan dipahami etika komunikasi dalam pembelajaran online melalui aplikasi zoom pada mahasiswa fakultas ilmu-ilmu sosial Universitas Dehasen Bengkulu,etika komunikasi mahasiswa kepada dosen cukup baik dikarenakan masih ada beberapa mahasiswa yang belum sepenuhnya dengan baik etika pada saat zoom seperti mematikan kamera dan audio. Sedangkan etika mahasiswa sesama mahasiswa pada saat perkuliahan zoom berlangsung juga cukup baik, seperti adanya menjaga sikap dan sopan santun pada saat berbicara, dengan sesama temanya walaupun masih ada beberapa mahasiswa yangn berbicaranya biasa saja seolah-olah sedang diluar, sehingga teman ataupun dosen bisa mendengar ucapan ataupun bahasa yang digunakan oleh mahasiswa kepada mahasiswa lainnya dalam ruang zoom tersebut. Disini etika itu terbagi menjadi dua bagian diantaranya deskriptif dan normatif. Peneliti menemukan bahwa dalam melakukan perkuliahan zoom, terdapat banyak kendala yang dihadapi mahasiswa, seperti halnya akses internet, kuota internet yang terbatas dan ada juga yang ketika mengikuti perkuliahan zoom tidak memperhatikan dosen yang lagi menjelaskan perkuliahan, salah satu contohnya mematikan audio dan kamera pada saat perkuliahan zoom berlangsung. Proses belajar melalui aplikasi zoom ternyata tidak sepenuhnya efektif di karenakan ada beberapa yang ditemukan seperti faktor sinyal karena banyak mahasiswa yang dari pedesaan, terbatasnya kuota internet karena tidak semua mahasiswa mempunya kuota yang cukup dan fasilitas bantuan kuota yang diberikan oleh kemetrian pendidikan dan kebudayaan (KEMENDIKBUD) tidak mencukupi. Sedangkan ini zoom, satu zoom bisa berapa kuota yang terpakai, selama ini mahasiswa harus paket hemat sehingga mematikan kamera dan audio demi menghemat kuota. Hal tersebut juga dibenarkan oleh beberapa orang informan dalam penelitian ini. Etika komunikasi mahasiswa perlu di perhatikan :

Maka dalam etika deskriptif proses perkuliahan melalui aplikasi zoom perlu memperhatikan etika komunikasi baik kepada dosen maupun sesama mahasiswa seperti halnya ketika seorang mahasiswa lagi berbicara dengan dosen harus lah bersikap yang sopan dalam artian tidak sambil bermain handphone dan jangan memotong pembicaraan dosen yang sedang berbicara, tidak menghidupkan kamera padahal tujuan dosen untuk menggunakan aplikasi zoom ini agar mahasiswa dapat bertatap muka secara langsung baik kepada dosen maupun kepada sesama mahasiswa, karena dengan memilih aplikasi zoom sebagai tempat untuk melakukan perkuliahan daring seharusnya kita bisa lebih memahami materi yang di sampaikan oleh dosen maupun diskusi dengan sesama mahasiswa karena didalam zoom kita bisa melihat secara langsung wajah teman maupun dosen dan tanggapan yang diberikan pada saat ada pertanyaan yang dilontarkan kepada kita melalui room chat kita bisa menulis pesan atau ingin bertanya dengan pertama mengucapkan salam awal pertanyaan. kita juga melihat keadaan sekitarnya dengan menghidupkan kamera dan audio yang ada. 
Dalam etika normatif perkuliahan melalui aplikasi zoom mahasiswa dan dosen melakukan interaksi pembelajaran selama masa pandemi, proses yang dilakukan selama perkuliahan melalui aplikasi zoom masih perlu memperhatikan etika dan aturan yang berlaku selama perkuliahan berlangsung, serta etika mahasiswa kepada dosen maupun etika mahasiswa kepada sesama mahasiswa itu masih harus dijaga, seperti halnya menjalankan peraturan yang sudah berlaku selama perkuliahan melalui aplikasi zoom berlangsung yang mana menuntut kita untuk taat terhadap apa yang sudah ditetapkan bersama serta etika mahasiswa kepada dosen maupun kepada sesama mahasiswa harus juga di jaga meskipun itu hanya lewat sebuah aplikasi zoom. Sebaiknya ada aturan baku yang dibuat oleh dosen langsung atau berdasarkankesepakatan bersama antara dosen dan mahasiswa pada saat awal perkuliahan.

Dari etika normatif tersebut dapat kita lihat dalam sebuah perkuliahan melalui aplikasi zoom seperti peraturan yang harus di patuhi bersama demi menjaga keamanan dan ketertiban perkuliahan, etika normatif ini ditegakkan untuk menegakkan kedisiplinan serta kejujuran dalam sebuah kelompok perkuliahan. Dalam perkuliahan zoom ini penulis belum menemukan adanya bentuk belajar atau kesepakatan yang dibuat sebagai aturan yang harus dipatuhi selama perkuliahan zoom berlangsung, etika normatif yang menjadi pedoman bagi mahasiswa maupun dosen untuk bertindak. Norma-norma tersebut sekaligus menjadi dasar penilaian bagi dosen tentang baik atau buruk, salah atau benar.Contoh dari etika normatif ini ialah seperti kejujuran, disiplin. Kejujuran perkuliahan zoom dapat dilihat dari intensitas mahasiswa selama mengikuti perkuliahan, misalnya pada aplikasi zoom kita bisa melihat seberapa sering mahasiswa keluar masuk ruang zoom. Karena ada beberapa mahasiswa yang sekali masuk karena faktor sinyal sehingga keluar dari zoom tersebut. Namun jika tidak ada keinginan untuk masuk kembali keruang zoom, maka disimpulkan mahasiswa tidak usaha untuk mencari sinyal untuk bisa masuk kembali atau memang sengaja tidak ingin masuk kembali. Kejujuran seperti ini lah yang penulis maksudkan tersebut karena tidak dapat di pastikan secara langnsung kebenarannya.

Selanjutnya kedisiplinan bagian dari dari etika juga, dalam perkuliahan melalui zoom, kedisiplinan dapat dilihat dari ketepat mahasiswa masuk dalam ruang zoom dan kemampuan menyelesaikan tugas perkuiahan tepat pada waktunya. Jadi menurut penulis meskipun perkuliahan di masa pandemi covid-19 melalui zoom namun etika mahasiswa tetaplah harus diterapkan.

Berdasarkan hasil penelitian dan pembahasan bahwa etika komunikasi mahasiswa pada perkuliahan pada aplikasi zoom khusus nya mahasiswa Fakuktas IImuIImu Sosial cukup baik. Menueurt penulis, ada baiknya mempertimbangkan tentang ke efektipan dalam pemilihan media belajar yang akan digunakan baik itu dari sisi kemudahan untuk di akses, hemat biaya dan ekonomis serta menarik minat mahasiswa untuk mengikuti perkuliahan daring baik itu di masa pandemic seperti sekarang ini ataupun di masa new normal.

Dan lebih bagus lagi, di uji coba terlebih dahulu sebelum memutuskan untuk memilih media tersebut sebagai pilihan yang tepat untuk media perkuliahan karena tidak semua baik dosen ataupun mahasiswa semuanya sudah tahu dan paham cara mengakses aplikasi zoom tersebut. Hal ini penulis sampaikan, agar terciptanya perkuliahan yang efektip dan efesien, sekian dan terima kasih. 


\section{KESIMPULAN DAN SARAN}

\section{Kesimpulan}

1. Etika Deskriptif, dalam perkuliahan zoom sudah tergolong cukup baik, karena mahasiswa ada beberapa ditemukan bahwa mahasiswa yang mematikan kamera dan audio, berbicara dengan orang lain diluar zoom tampa izin, mahasiswa ada yang keluar masuk zoom, sehingga etika di nilai cukup baik

2. Etka Normatif, etika ini berhubungan dengan aturan dan sanksi. Dalam perkuliahan zoom belum ada aturan dan sanksi yang tegas yang berlaku atau yang disepakati bersama oleh dosen dan mahasiswa. Sehingga etika komunikasi mahasiswa di simpulkan cukup baik karena masih ada yang berbicara dengan menggunakan bahasa daerah dan mahasiswa ada yang belum disiplin dalam kehadiran dan pengumpuan tugas.

\section{Saran}

1. Perlunya kesepakatan antara mahasiswa dan dosen melalui kontrak belajar dan etika di ikuti selama proses perkuliahan berlangsung.

2. Mahasiswa harus mengikuti peraturan dan perlunya sanksi tegas supaya mahasiswa disiplin dalam proses belajar mengajar.

3. Hendaknya selama perkuliahan zoom berlangsung mahasiswa tetap menerapkan etika komunikasi meskipun tidak ada aturan yang dibuat oleh dosen, baik itu etika pada saat berbicara kepada dosen maupun kepada sesama mahasiswa.

\section{DAFTAR PUSTAKA}

Aburahman Hasan dan Asep, 2014. Aplikasi pinjaman pembayaran secara kredit pada Bank Yudha Bhakti. Jurnal computech \& Bisnis, Vol. 8 no 2.

Bakar Abu fahmi (2011). Mencerna situs jejaring sosial.Jakarta:Elex media komputindo.

Barlund Dean C. "Towara Meaning-Centered Philosophy of communication",Jurnal of Comunication,12(Desember 192).

Brahma, I, A.(2020). Penggunaan Zoom sebagai pembelajaran berbasis online dalam mata kuliah sosiologi dan Antropologi pada mahasiswa PPKNdi STKIP 
Kusumanegara Jakarta. Aksara: jurnal ilmu pendidikan. Nonformal, 6(2) 97. https://doi.org/10.37905/aksara.6.2.97-102.2020.

Christina Hoff Sommers,"Ethics Without Virtue:Moral Education in America",The American Scholar,53(Muslim Panas,1984).

Dabbagh, N. and Ritland. B.B. ( 2005). Online Learning, Concepts, Strategies And Application. Ohio: Pearson.

Hermawan, C.W.(2009). Cara mudah membuat komunikasi online dengan PHPBB, Yogyakarta.

https://www,dosen pendidikan.co.id/etika adalah.13 jan 2021.

https://www.coursehero. Com/file/p4j4e5s/Drs H Burhanudin Salam.etika adalah cabang yang berbicara mengenai.

https://inet.detik.com/mobile-apps/d-5045757/google-classroom-pengertian-dan-caramenggunakannya.

https:// Scholar. Google. Co.id / citations ? use= QztGfcAAAAJ\&HI-ID

Kompasiana.com/ayunp/54f76886a33311c4528b4570/grup-whatsapp.

Mulyana Dedy . (2014). Perkembangan informasi :New media, jurnal umum unpas, terbitan mei 2014.

Miller.Gerald R."Contributions of Communication Research to the Study of Speech", dalam Alan H.Monroedan DouglasEhninger, Principles and Types of Speech Communication,edisiringkaske -6(Glenview,Ill;Scott, Foresman,1969).

Mutiah Tuty, dkk, Etika komunikasi dalam menggunakan media sosial. Jurnal Global.2019 Fakultas ilmu sosial dan ilmu politik UPN Veteran Jakarta.

N, Gunnar Andr_, Media and Morals,Stockholm:Akademilitterature,1978.

Pengertian-Aplikasi.html\#: :text=Menur-Marimi-dkk.(2011A,digunakan-dalamcomputer-ole-pengguna. Thomas R. Nilsen, Ethcs of Speech Comminication, edisi ke-2 (Indianapolis; Bobbs- Merrill, 1974).

www. Journal. Sociolla. Com 02 Nov 2020 